\title{
Treacher Collins syndrome and implications in the oral cavity
}

\author{
Duque C and Lopes Cardoso I* \\ Health Sciences Faculty, University Fernando Pessoa, Porto, Portugal
}

\begin{abstract}
Background and Objective: Treacher Collins syndrome, also called mandibula-facial dysostosis, is a congenital disorder. It is the aim of this work to clarify the etiology, diagnosis, phenotypic craniofacial and oral characteristics of the syndrome, as well as to discuss the treatments to be applied.

Methods: A bibliographic search was performed using the keywords: "Treacher Collins Syndrome", "treatment", "dental", "oral cavity", "TCOF1 gene".

Results: Most cases have an autosomal dominant transmission and variable expressivity. Mutations in the TCOF1 gene on chromosome 5 are usually known to cause Treacher Collins syndrome. The phenotypic craniofacial features are: micrognathia, maxillary hypoplasia with palate cleft, malar hypoplasia, antimongoloid inclination of palpebral fissures, coloboma of lower eyelid and microtia. Problems in the oral cavity are frequent in these patients because the deficiencies of the bone bases provoke crowding and can lead to incorrect bite. Other oral manifestations include reduced salivary flow, high levels of caries and plaque.
\end{abstract}

Conclusions: Diagnosis and treatment should be performed in an early stage and are important for the reestablishment of masticatory, respiratory and auditory functions.

\section{Introduction}

The Treacher Collins syndrome (TCS), also known as mandibulafacial dysostosis or Franceschetti-Zwahlen-Klein syndrome, is a congenital pathology characterised by abnormal craniofacial development resulting from changes in embryo development of the first and second gill arches between the fifth and eight weeks of foetal development [1]. It is a rare condition with an incidence of 1:50.000 live births [2], without predisposition for sex or race [3].

It is caused by mutations on the TCOF1 gene, but other two genes have also been identified.

Around $40 \%$ of all cases of this syndrome have a hereditary origin, while the remaining $60 \%$ result from de novo mutations [4].

Clinical characteristics of this syndrome are usually bilateral and relatively symmetrical [5] and patients also show multiple oral changes $[6,7]$. The craniofacial anomalies present in these patients may lead to chewing, breathing and speech problems that should be evaluated as a priority [8].

The treatment of this condition requires a multidisciplinary approach based on the degree of dysmorphology and growth of each anatomical region in order to optimize both functional and aesthetic rehabilitation [9].

Differential diagnosis should be made with other clinical entities that have features common to this disease, such as Nager, Miller, Goldenhar and Pierre Robin syndromes [10].

The main objective of this work is to obtain a deeper knowledge of the most frequent genetic factors, craniofacial characteristics and oral manifestations, in order to offer them a valid dental treatment adapted to their needs.
For this work, a bibliographic search was performed using the websites PubMed, SciELO and ScienceDirect.

The keywords used were: "Treacher Collins Syndrome", "treatment", "dental", "oral cavity", "TCOF1 gene". The selection criteria of the articles were: date of publication between 2012 and 2019 and written in Portuguese, English, Spanish or French. Papers prior to 2012 were also selected according with the relevance of the theme.

\section{Treacher Collins Syndrome}

\section{Historical Considerations}

This syndrome was first described by Thompson in 1846. Later, in 1889, George Andreas Berry described the syndrome as a congenital disease with coloboma of the lower parates. The name of this syndrome comes from the English ophthalmologist Edward Treacher Collins, who, in 1900 diagnosed the condition in 2 patients with these eye sequelae and thus determined the essential features of this condition [11].

In 1940, Adolphe Franceschetti together with David Klein published numerous review papers where they characterized facial features and adopted for this condition the name mandibulofacial dysostosis [12].

${ }^{*}$ Correspondence to: Lopes Cardoso I, Faculdade de Ciências da Saúde, Universidade Fernando Pessoa Rua Carlos da Maia, 296, 4200-150 Porto, Portugal, Tel: +351 225071300; E-mail: mic@ufp.edu.pt

Key words: Treacher Collins Syndrome, treatment, dental, oral cavity, TCOF1 gene Received: September 20, 2019; Accepted: October 01, 2019; Published: October 04, 2019 
Other designations for this syndrome used today are jaw-facial dysostosis or Franceschetti-Zwahlen-Klein syndrome [13].

\section{Etiopathogeny}

TCS is a rare congenital disorder of craniofacial development caused by mutations in the TCOF1 gene, located on the long arm of chromosome 5 (5q32-q33), or in the POLR1C and POLR1D genes present on chromosomes 6 and 12 respectively (6q21.2 and 13q12.2) [14].

The TCOF1 gene encodes Treacle nuclear phosphoprotein, involved in bone and other facial tissue development during the prenatal stage. So far over 200 mutations have been identified in this gene and all of them lead to the appearance of a premature stop codon. The TCOF1 gene is responsible for most cases (>90\%) of this syndrome, having an autosomal dominant transmission. However, in many cases mutations in this gene may arise without the presence of family history [11].

On the other hand, the POLR1D and POLR1C genes encode the $\mathrm{D}$ and $\mathrm{C}$ subunits of RNA polymerases I and III, respectively, involved in the synthesis of ribosomal pre-RNAs and small RNA molecules (siRNAs), which are essential for the normal functioning and survival of cells [15]. So far, there is a number of identified pathogenic mutations, including insertions, deletions, nonsense mutations, and missense mutations in these two genes, however, approximately $60 \%$ of TCS patients have no family history, resulting the syndrome from de novo mutations [16].

Mutations in these genes alter the structure and function of the encoded protein, reducing the amount of RNA polymerases I and III in cells, thereby leading to lower rRNA production. Decreased rRNA is thought to trigger the apoptosis process in neural ectodermal cells. Since these cells are the precursors of the neural crest, neural crest cell formation will also be compromised. These cells contribute to the formation of bones, cartilage and connective tissue of the head and face. This may explain the cranioskeletal hypoplasia characteristic of TCS individuals [17].

Thus, Dixon, et al. [18] suggested that the cranioskeletal hypoplasia commonly observed in TCS individuals is caused by a deficiency in neural crest cells rather than a migration defect of these cells $[11,18]$.

Recent studies show that deficiencies in neural ectodermal and neural crest cells result in the activation of the nucleolar stress of the p53 protein-dependent apoptotic pathway that promotes neuroepithelial cell death. This finding raises the possibility that inhibition of p53 protein activity could block neuroepithelial apoptosis, restore the neural crest cell population, and prevent craniofacial anomalies characteristic of TCS [17]. However, p53 carries out several important cellular functions, including its role as a tumour suppressor. Often p53 loss results in tumour formation. Therefore, further study is needed for a deeper understanding, specifically of non-cancer-linked genes and tumour progression as potential candidates for the therapeutic prevention of TCS and other craniofacial syndromes [7].

The reason for the clinical variability observed in TCS patients is still unknown. Some authors attribute the wide diversity of symptoms to environmental factors, interaction with other genes, and the role of normal alleles of the TCOF1 gene. So far, no author has been able to find a clear relationship between the severity of the clinical picture and the type or location of the pathological mutation $[11,19]$.

\section{Clinical features}

The symptoms and severity of this syndrome differ from individual to individual, even among members of the same family. However, there are distinctive and well-described clinical features [20].

The clinical features of Treacher Collins Syndrome reflect the abnormal embryonic development of structures derived from the first and second pharyngeal arches. Most of the present changes are bilateral with relatively symmetrical distribution [21].

Some of the main symptoms of Treacher Collins Syndrome are malar hypoplasia, maxillary and mandibular hypoplasia and bilateral microtia or annotation [22].

In general, patients present alterations of the external ear or even absence of it. This is accompanied by atresia or stenosis of the external acoustic meatus, so hearing loss which is usually bilateral is very likely. At the middle ear level there is ankylosis of the ossicles or absence of them [23]. The facial profile of these patients is dramatically convex due to marked micrognathia [24]. Micrognathia along with glosoptosis may lead to a greater predisposition to airway obstruction, which may lead to feeding and breathing problems [25].

Ocular changes are frequent and include antimongoid tilt of the eyelid fissures, lower eyelid coloboma and partial absence of eyelashes in the lower eyelid. Occasionally, patients may have vision loss, strabismus, congenital cataracts and even microphthalmia or anophthalmia. Despite these changes, vision is usually normal because the retina does not develop from the affected branchial arches. Thus, most patients maintain at least one eye with normal vision [20].

Due to bone malformation, swallowing, chewing, speech and breathing are affected. There are also manifestations in other areas of the body such as congenital heart disease, cryptorchidism and malformation of the cervical spine and extremities [26].

Cognitive development is usually normal but is affected by speech development problems resulting from hearing loss or cleft palate [27].

Oral characteristics: Regarding the oral cavity, high levels of plaque and low effectiveness of tooth brushing have been described in patients with TCS [28]. In addition, these patients experience reduced saliva flow as a result of salivary gland pathology. This factor along with others like mouth breathing, crowding and soft diet contribute to high levels of tooth decay. However, studies in children and adults with regular dental follow-up have shown a satisfactory oral health standard without high caries levels, reflecting the importance of a prophylactic treatment [29]. These authors evaluated the prevalence of dental anomalies in 15 patients with TCS, observing their presence in $60 \%$ of them, with higher incidence of dental agenesis (33\%), especially of the lower second premolars, and enamel opacities (20\%) [28].

Other manifestations associated with the oral cavity also occur, such as unilateral or bilateral macrostomy, ogival palate and occasionally cleft palate [10].

In another study, Østerhus, et al. [30] attempted to relate TCS with salivary gland pathology and dysfunction in a sample of 21 patients. These researchers observed that half of those patients had major salivary gland dysplasia or aplasia. However, no significant correlation was found between oral dryness complaints and low salivary secretion rates. The results suggested an association between TCS and salivary gland pathology [30]. 
A highlight is the hypoplasia of the facial bones, especially of the middle third of the face and jaw. This change gives rise to a bird's face with a prominent nose and a narrow face with depressed cheeks [31]. Jaw hypoplasia can lead to difficulties in breathing and eating. It also has repercussions in the oral cavity and may, in most cases, leads to dental malocclusion with anterior open bite [32].

Terner, et al. [21] found that mandibular hypoplasia is more severe at the proximal level, thus the condyle is the most hypoplastic structure followed by the ramus and then the body. This implies a high incidence of TMJ dysfunction in these patients, which may cause mouth opening limitation [21].

Patients can also develop several diastemas along the arches, badly positioned teeth, enamel hypoplasia, temporomandibular joint dysplasia, midline deviation, Class II or III malocclusion, prognathism or maxillary retrognathism relative to the skull base [28].

\section{Diagnosis}

Treacher Collins syndrome presents a very variable clinical picture, even among members of the same family, which associated with the high rate of de novo mutations can lead to misdiagnosis.

The diagnosis of these patients is essentially clinical and is usually made at birth based on the observed clinical manifestations. This diagnosis is confirmed by radiographic findings and molecular studies [33].

Diagnosis can also be made in the prenatal period by sampling chorionic villi (10-12 weeks gestation) or by amniocentesis (15-18 weeks gestation) [34]. Although molecular analysis has been shown to be extremely valuable in prenatal diagnosis, the degree of fetal alteration cannot be predicted. Consequently, ultrasound can provide information on the severity of affected pregnancies and can be used to assess fetal progression by revealing typical facial dysmorphism with bilateral ear anomalies [35].

In cases of suspicion in the family, genetic analysis can determine the presence of the mutation causing Treacher Collins syndrome, allowing to determine changes in the TCOF1, PORL1C and PORL1D genes. This is especially important for genetic counselling in high-risk families due to the high penetrance and variable expressiveness of the syndrome, as the condition may go unnoticed in some individuals who may pass it on to offspring [2].

It is important to make a differential diagnosis with other syndromes involving craniofacial malformations, such as: Nager, Miller and Goldenhar syndromes [36].

\section{Treatment}

There is no cure for this condition. Thus, treatment is directed to the specific symptoms of each individual. Treatment of this disease requires a multidisciplinary approach involving different health professionals such as craniofacial surgeons, orthodontists and dentists, physiotherapists, paediatricians, psychologists, otolaryngologists and ophthalmologists, among other professionals who may be required [36].

Patients with TCS usually require numerous surgical procedures and staged treatment can continue throughout childhood until adulthood, as some surgeries should be postponed until the end of growth. Early intervention during the neonatal period and childhood may be necessary to ensure airway integrity, nourishment and speech development [20]. Thus, early evaluation of possible airway obstruction, resulting from retromicrognathy that contributes to the restriction of nasopharyngeal spaces, is necessary. In mild cases conservative treatment and prone position may be sufficient. If the respiratory obstruction is more severe, lip-tongue adhesion or mandibular advancement may be required. In more severe cases, intubation or tracheotomy may be required. In cases that do not respond satisfactorily to tracheotomy, osteogenic distraction of the mandible is an alternative. However, the latter is usually reserved to assist decannulation after tracheotomy [37].

Continuous airway monitoring is necessary during child growth, as respiratory complications may develop later [38].

In a second stage, between 3 and 12 years old, orthodontic treatment, reconstruction of the palate and zygomatic region should be started. In addition, otoplasty and other retouching surgeries should also be performed during this period.

Although peri-orbital soft tissue defects are well known, true ophthalmologic sequelae are rarely mentioned [39]. However, the eyes of these patients are characterized by antimongoloid tilt of the eyelid fissures resulting from lower eyelid coloboma. In this context, lower eyelid colobomas need special attention from birth because they are a potential threat to vision [40]. Although eyelid and orbital deformations are hallmarks of this syndrome, its correction is usually delayed, excluding neonatal tarsorrhaphy in cases with corneal exposure [20].

The cleft palate is a trait usually found in TCS, with an approximate incidence of $23 \%$. Cleft palate repair is often delayed until airway function is no longer compromised. In addition, after palate repair, a higher risk of palate fistula is often reported, although not much evidence is provided [41].

Conductive hearing loss is present in most patients, resulting from abnormal internal auditory structure and improper functioning of the ossicles. Thus, early identification of the cause of hearing loss and its correction before school entry is of special importance. An elastic band hearing aid can be used in the first years of life [40]. If patients have partial microtia or total annotation, the auricle is reconstructed using prosthetic devices or an autologous costal cartilage structure [3,20]. Even though the cartilage is strong enough from 6 years of age, it is preferable to perform the procedures around 9 years of age $[3,42]$.

Cheek reconstruction is usually directed to the correction of absent or hypoplastic zygoma. For the increase of zygomatic prominences and orbital border, cranial bone graft is generally used, however it has the disadvantage of presenting a higher percentage of bone resorption [43].

In a third phase, from 13 to 18 years old, orthognathic surgery is advised. In cephalometric analysis, patients with TCS have a short and retrognathic jaw, which may lead to glosoptosis and upper airway obstruction. The height of the posterior face is reduced, the angle of the mandibular plane is increased, and patients may present anterior open bite. Usually, the association of Le Fort I maxillary osteotomy, sagittal mandible osteotomy and genioplasty is performed. In situations where the mandibular deformation is greater, with reduction of the mandibular ramus dimensions, osteogenic distraction of the mandibular ramus is previously performed to provide greater bone contact in the sagittal osteotomy [24].

Finally, nasal reconstruction is performed after orthognathic surgery, and according to individual needs [8].

Dental treatment of patients with Treacher Collins syndrome: Dental treatment of TCS patients can be a real challenge for dentists due to patient anxiety, limited mouth opening ability, hearing impairment 
and micrognathia, which contribute to the development of respiratory problems. Given the difficult intubation of these patients, dental treatment under general anaesthesia may be safer than outpatient or sedation intervention [28].

Orthodontics in conjunction with orthognathic surgery allows us to correct jaw and jaw growth defects $[39,44]$. These patients usually have no teeth or misplaced teeth. In this way, orthodontics can help improve bite and intercuspidation. However, in many cases extractions and implant placement may be necessary, as the various surgical interventions associated with bone deficiency make any damage to the roots of the tooth more likely $[20,45]$.

In these patients, oral hygiene can be a problem. Dalben, et al. [28] demonstrated a high rate of plaque resulting from poor tooth brushing. This leads to a high frequency of restorative needs. In this context, there is a great need to establish a regular dental follow-up program for these patients. Caregivers should be informed of the importance of maintaining daily oral hygiene and should encourage patients to take responsibility for their care at home [28].

\section{Prognosis}

Treacher Collins syndrome is not a progressive disease and, in most cases, affected children achieve normal development and intelligence.

The prognosis of mild and moderate forms of this disease is favourable with the implementation of appropriate treatment. However, careful and insightful attention will ensure better school performance [35].

\section{Discussion}

Treacher Collins syndrome is a congenital disease associated with bilateral symmetrical anomalies of structures originating from the 1st and 2nd pharyngeal arches [8]. It is a condition with high penetrance and variable expressivity. If a parent is affected by this syndrome, there is a $50 \%$ probability of transmitting to the offspring the mutant gene responsible for the disorder [46].

The main gene involved in the development of TCS is TCOF1, present in the long arm of chromosome 5, which encodes the Treacle protein [47]. Although there has been strong progress in the molecular characterization of this syndrome, there is still no explanation for its variability of clinical manifestations, even in patients of the same family [10].

In Treacher Collins syndrome, both jaw and jaw are hypoplastic. Dental malocclusion is frequent due to hypoplasia of the mandible and ogival palate. In most cases the predominant dental malocclusion is crowding, mainly due to bone base deficiency $[48,49]$.

In this context, dental treatment, especially orthodontic treatment, plays an important role.

Macrostomy and cleft palate appear in $35 \%$ of cases $[16,50]$. According to Thomé [51], cleft palate involvement is a very important factor regarding breastfeeding and feeding difficulties presented by these individuals. The cleft palate directly impairs the negative pressure that the baby exerts on the mouth during breastfeeding, which often makes milk suction difficult [31]. In this sense, the dentist plays a fundamental role in determining the need for diet adequacy according to the degree of oral changes, as well as guiding parents about feeding techniques and aspiration prevention.
These patients require special attention from dentists, since the alterations observed in the stomatognathic system, as well as the oral manifestations, negatively affect the oral health.

The diagnosis of TCS is mainly clinical and is usually made soon after birth. It can also be performed prenatally by ultrasonography and biopsy of chorionic villi. Moreover, many investigators recommend diagnostic confirmation through molecular testing and, in some cases, a detailed and careful family history as TCS shares several phenotypic features with other craniofacial syndromes.

The treatment of these patients is long and has a major impact on their lives and their families. Treatment usually requires numerous surgeries with numerous facial structures needing surgical correction. Therefore, it is important that these interventions be performed at an appropriate age in order to proceed without causing compromise in other procedures that may be requested later [8].

Therefore, therapeutic strategies for TCS patients require a multidisciplinary medical team, where all aspects of the disorder should be evaluated.

\section{Conclusion}

Although TCS is a rare congenital disease, it is important to know it so that an early diagnosis can be made to provide the patient with the best possible treatment, knowing that it is not just a dental intervention but a multidisciplinary team, where each plays a different role to improve the patient's quality of life. In this context, further studies are needed for a better understanding of the etiopathogenesis of this syndrome, which will guide therapeutic solutions for prevention and correction of both functional and aesthetic changes.

\section{References}

1. Tse WK (2016) Treacher Collins syndrome: New insights from animal models. Int $J$ Biochem Cell Biol 81: 44-47. [Crossref]

2. Chen Y, Guo L, Li CL, Shan J, Xu HS, et al. (2018) Mutation screening of Chinese Treacher Collins syndrome patients identified novel TCOF1 mutations. Mol Genet Genomics 293: 569-577. [Crossref]

3. Cobb AR, Green B, Gill D, Ayliffe P, Lloyd TW, et al. (2014) The surgical management of Treacher Collins syndrome. Br J Oral Maxillofac Surg 52: 581-589.

4. Wang Y, Yin XJ, Han T, Peng W, Wu HL, et al. (2014) A novel silent deletion, an insertion mutation and a nonsense mutation in the TCOF1 gene found in two Chinese cases of Treacher Collins syndrome. Mol Genet Genomics 289: 1237-1240.

5. Katsanis SH, Jabs EW (2004) Treacher Collins syndrome. In: Adam MP, Ardinger HH, Pagon RA[Eds) GeneReviews ${ }^{\circledR}$. Seattle (WA): University of Washington, Seattle.

6. Martelli-Junior H, Coletta RD, Miranda RT, Barros LM, Swerts MS, et al. (2009) Orofacial features of Treacher Collins Syndrome. Med Oral, Patol Oral Cir Bucal 14: E344-348.

7. Trainor PA, Dixon J, Dixon MJ (2009) Treacher Collins syndrome: etiology, pathogenesis and prevention. Eur J Hum Genet 17 :275-283.

8. Yoshida M, Tonello C, Alonso N (2012) Síndrome de Treacher Collins: desafio na otimização do tratamento cirúrgico. Rev Bras Cir Craniomaxilofac 15: 64-68.

9. Posnick JC, Tiwana PS, Costello BJ (2004) Treacher Collins syndrome: Comprehensive evaluation and treatment. Oral Maxillofac Surg Clin North Am 16: 503-523.

10. Spezzia S (2018) Repercussões Bucais da Síndrome de Treacher Collins: revisão de literatura. J Oral Invest 7: 89-97.

11. Franceschetti A, Klein D (1949) The mandibulofacial dysostosis; a new hereditary syndrome. Acta ophthalmol 27: 143-224.

12. Scully C, Langdon J, Evans J (2011) Marathon of eponyms: 20 Treacher Collins syndrome. Oral Dis 17: 619-620. [Crossref]

13. Dauwerse JG, Dixon J, Seland S, Ruivenkamp CA, van Haeringen A, et al. (2011) Mutations in genes encoding subunits of RNA polymerases I and III cause Treacher Collins syndrome. Nat Genet 43: 20-22. 
14. Mohan RP, Verma S, Agarwal N, Singh U (2013) Treacher Collins syndrome: a case report. BMJ Case Rep 2013. [Crossref]

15. Sakai D, Trainor PA (2009) Treacher Collins syndrome: unmasking the role of Tcofl/ treacle. Int J Biochem Cell Biol 41: 1229-1232.

16. Dixon J, Edwards SJ, Anderson I, Brass A, Scambler PJ, et al. (1997) Identification of the complete coding sequence and genomic organization of the Treacher Collins syndrome gene. Genome Res 7: 223-234.

17. Splendore AC (2002) Estudo molecular do gene TCOF1 em pacientes portadores da síndrome de Treacher Collins. Tese de doutoramento, Instituto de Biociências, Universidade de S. Paulo.

18. Chang CC, Steinbacher DM (2012) Treacher collins syndrome. Semin Plast Surg 26: 83-90. [Crossref]

19. Terner JS, Travieso R, Chang C, Bartlett SP, Steinbacher DM (2012) An analysis of mandibular volume in Treacher Collins syndrome. Plast Reconstr Surg 129: 751e-753e.

20. Travieso R, Chang CC, Terner JS, Beckett J, Wong K, et al. (2013) A range of condylar hypoplasia exists in Treacher Collins syndrome. J Oral Maxillofac Surg 71: 393-397.

21. Takegoshi H, Kaga K, Kikuchi S, Ito K (2000) Mandibulofacial dysostosis: CT evaluation of the temporal bones for surgical risk assessment in patients of bilateral aural atresia. Int J Pediatr Otorhinolaryngol 54: 33-40.

22. Chong DK, Murray DJ, Britto JA, Tompson B, Forrest CR, et al. (2008) A cephalometric analysis of maxillary and mandibular parameters in Treacher Collins syndrome. Plast Reconstr Surg 121: 77e-84e.

23. Ali-Khan S, Runyan C, Nardini G, Shetye P, Staffenberg D, et al. (2018) Treacher Collins Syndrome and Tracheostomy: Decannulation Using Mandibular Distraction Osteogenesis. Ann Plast Surg 81: 305-310. [Crossref]

24. Lopes da Silva D, Neto FXP, Carneiro SG (2008) Síndrome de Treacher Collins: revisão de literatura. Arq Int Otorrinolaringol 12: 116-121.

25. Wulfsburgh EA (2003) Treacher Collins syndrome. In: NORD guide to rare disorders. Lippincott Williams \& Wilkins. Philadelphia, PA pp. 262-263.

26. Dalben GS, Costa B, Gomide MR (2006) Prevalence of dental anomalies, ectopic eruption and associated oral malformations in subjects with Treacher Collins syndrome. Oral Surg Oral Med Oral Pathol Oral Radiol Endodontol 101: 588-592.

27. Åsten P, Skogedal N, Nordgarden H, Axelsson S, Akre H, et al. (2013) Orofacial functions and oral health associated with Treacher Collins syndrome. Acta Odontol Scand 71: 616-625.

28. Østerhus IN, Skogedal N, Akre H, Johnsen UL, Nordgarden H, et al. (2012) Salivary gland pathology as a new finding in Treacher Collins syndrome. Am J Med Genet 158A: $1320-1325$.

29. Oliveira ACB, Ramos-Jorge ML, Paiva SM (2003) Síndrome de Treacher Collins em Odontopediatria. J Bras Odontopediatr Odontol Bebê Curitiba 6: 223-228.

30. Ribeiro RC (2014) Anomalias congénitas e manifestações orais. Dissertação de Mestrado Integrado em Medicina Dentária, Faculdade de Ciências da Saúde, Universidade Fernando Pessoa.

31. Van Gijn DR, Tucker AS, Cobourne MT (2013) Craniofacial development: current concepts in the molecular basis of Treacher Collins syndrome. Br J Oral Maxillofac Surg 51: 384-388.

32. Kadakia S, Helman SN, Badhey AK, Saman M, Ducic Y (2014) Treacher Collins Syndrome: the genetics of a craniofacial disease. Int J Pediatric Otorhinolaryngol 78 : 893-898.
33. Alfonso LS, Centelles IA (2016) Síndrome de Treacher Collins en una familia cubana Presentación de caso. Rev Habanera Cienc Méd 15: 408-417.

34. Andrade EC, Júnior VS, Didoni AL, Freitas PZ, Carneiro AF, et al. (2005) Treacher Collins syndrome with choanal atresia: a case report and review of disease feaures. Braz J Otorhinolaryngol 71: 107-110.

35. Miloro M (2010) Mandibular Distraction Osteogenesis for Pediatric Airway Management. J Oral Maxillofac Surg 68: 1512-1523.

36. Perkins JA, Sie KC, Milczuk H, Richardson MA (1997) Airway management in children with craniofacial anomalies. Cleft Palate Craniofac J 34: 135-140.

37. Posnick JC, Ruiz RL (2000) Treacher Collins Syndrome: current evaluation, treatment, and future directions. Cleft Palate Craniofac J 37: 434-434.

38. Plomp RG, van Lieshout MJ, Joosten KF, Wolvius EB, van der Schroeff MP, et al (2016) Treacher collins syndrome: a systematic review of evidence-based treatment and recommendations. Plast Reconstr Surg 137: 191-204.

39. Bresnick SD, Walker J, Clarke-Sheehan N, Reinisch J (2003) Increased fistula risk following palatoplasty in Treacher Collins syndrome. Cleft Palate Craniofac J 40: 280 283.

40. Firmin F (2010) State-of-the-art autogenous ear reconstruction in cases of microtia. $A d v$ Otorhinolaryngol 68: 25-52. [Crossref]

41. Fan KL, Federico C, Kawamoto HK, Bradley JP (2012) Optimizing the timing and technique of Treacher Collins orbital malar reconstruction. J Craniofac Surg 23(7 Suppl 1): 2033-2037.

42. Regezi JA, Sciubba J (2017) Oral pathology: clinical pathologic correlations. (7th Edn) Elsevier.

43. Freitas RS, Tolazzi AR, Alonso N, Cruz GA, Busato L (2008) Evaluation of molar teeth and buds in patients submitted to mandible distraction: long-term results. Plast Reconstr Surg 121: 1335-1342.

44. Yan Z, Lu Y, Wang Y, Zhang X, Duan H, et al. (2018) Identification of a novel TCOF mutation in a Chinese family with Treacher Collins syndrome. Exp Ther Med 16: 2645 2650.

45. Vincent M, Geneviève D, Ostertag A, Marlin S, Lacombe D, et al (2016) Treacher Collins syndrome: A clinical and molecular study based on a large series of patients. Genet Med 18: 49-56.

46. Shafer WG, Levy BM (1987) Doenças dos ossos e das articulações. Tratado de Patologia Bucal. (4th Edn) Guanabara Koogan.

47. Schaefer GB, Thompson JN (2014) Medical Genetics. An integrated approach. (1st Edn) McGraw-Hill Education.

48. Posnick JC (1997) Treacher Collins syndrome: perspectives in evaluation and treatment. J Oral Maxillofac Surg 55: 1120-1133.

49. Thomé S (1990) Estudo da prática do aleitamento materno em crianças portadoras de malformação congénita de lábio e/ou palato. Dissertação de Mestrado. Escola de Enfermagem de Ribeirão Preto, Universidade de São Paulo.

50. Edwards SJ, Fowlie A, Cust MP, Liu DT, Young ID, et al. (2008) Prenatal diagnosis in Treacher Collins syndrome using combined linkage analysis and ultrasound imaging. JMed Genet 33: 603-606.

51. Leyva J (2014) Síndrome de Treacher Collins: revisión de tema y presentación de caso Universitas Méd 55: 64-70.

Copyright: (C2019 Duque C. This is an open-access article distributed under the terms of the Creative Commons Attribution License, which permits unrestricted use, distribution, and reproduction in any medium, provided the original author and source are credited. 